\title{
Vertical Handoff Decision System based on Support Vector Machine
}

\author{
Ryong $\mathrm{Oh}^{*}$, Jaehak $\mathrm{Yu}^{\star *}$, Tae-sub Kim*, Chi-Hun Lim* Regular Members, \\ Seung-Wan $\mathrm{Ryu}^{\star * *}$, Choong-Ho Cho* Lifelong Members
}

\begin{abstract}
It is expected that many heterogeneous wireless systems, such as 3GPP LTE systems, WiMAX systems and WLAN systems, will coexist in the next generation wireless communication environments. Integrated radio resource management and seamless vertical handoff (VHO) should be supported to provide integrated communication services over multi-radio access networks. A new class of adaptive VHO system that views the handoff problem as a pattern recognition problem is proposed. In this paper, we propose a unified radio resource management (URRM) architecture and Support Vector Machine (SVM) based vertical handoff decision system. Extensive simulation studies show the proposed VHO algorithm outperforms RSS based VHO algorithms in terms of throughput and service cost.
\end{abstract}

Key Words : Vertical Handoff Decision, Heterogeneous Wireless Networks, Pattern Recognition, Support vector Machine

\section{Introduction}

It is expected that many heterogeneous wireless networking (HWN) systems, such as 3GPP LTE systems, WiMAX systems and WLAN systems, will coexist in the next generation wireless communication environments. This networking environment, the so called multi-radio access technologies (RAT) environment, could give a mobile user access to networks simultaneously in an Always Best Connected fashion ${ }^{[l]}$. Vertical handoff (VHO) between different RATs is a key factor to support seamless mobility for real-time applications when a mobile node $(\mathrm{MN})$ crosses the overlay multi-RAT networks. The IMT-Advanced system is expected to provide seamless service across many heterogeneous wireless networks through VHO. The handoff process in the packet-switched $4 \mathrm{G}$ wireless system is apparently a more critically challenging task than in traditional wireless networks due to the existence of more bandwidth intensive multimedia applications, client mobility and other metrics such as monetary cost.

Related works on VHO have been presented in recent research literature but still much more works needs to be done. The VHO decision is an involved issue in HWNs and takes on a substantial role in RRM frameworks ${ }^{[2]}$. Most approaches, e.g. [3] to network selection resort to a form of "network score function" where the different networks are rated through normalizing and weighing different criteria such as network properties, available interfaces and user preferences. However, some of the works have taken the received signal strength as the sole element of network choice in HWNs. While signal strength is mandatory in determining a network's availability, it remains only a single factor in determining the most appropriate network.

※ This research was supported by Basic Science Research Program through the National Research Foundation of Korea (NRF) funded by the Ministry of Education, Science and Technology (2010-0025125)

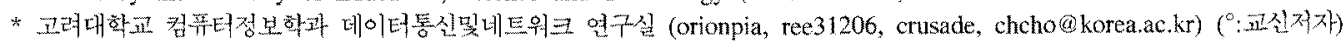

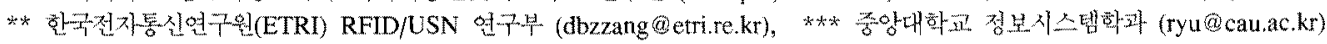

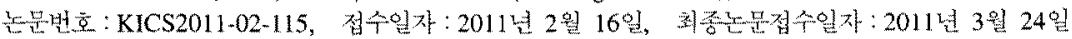


Notwithstanding, general complexity of network selection have lead researchers to propose heuristics, the use of logical, rule-based and policy-based frameworks and neural networks ${ }^{[4-7]}$.

The handoff problem is formulated as a pattern recognition problem in [8] to solve the complexity problem. Pattern recognition identifies meaningful regularities in noisy or complex environments. These techniques are based on the idea that the points that are close to each other in a mathematically defined feature space represent the same class of objects or variables. Previous work on using pattern recognition techniques for handoff-related purposes includes ${ }^{[9]}$. Reference ${ }^{[9]}$ uses hidden Markov models for pattern recognition of signal strength patterns for user location. It also mentions that the proposed pattern recognition techniques could possibly be used for various system fumctions like handoff. More recent work on pattern recognition for handoff algorithms is described in [10], which uses probabilistic neural networks and attempts much more extensive tracking of user location than do the algorithms in this paper.

Support Vector Machine (SVM) is a new well-founded and largely used valid machine learning algorithm ${ }^{[11]}$. They have been well used for pattern recognition, regression estimation, prediction, etc. and proved to be very effective on several real-world problems such as Internet traffic classification and Intrusion detection system ${ }^{[12]}$. SVM poses great potential and superior performance as appeared in many previous researches. SVM is a convenient and compact way of implementing a multiple criteria handoff decision algorithm. We thus employ SVM to the VHO decision. The main contributions of our paper are as follows:

URRM architecture and a SVM-based handoff decision system are proposed to support both accurate and real time decision making which can result in higher capacity and better overall link quality than what is available with today's systems, in which the dynamics of the future multi-RAT environment are very complex.

VHO message flow and procedures are presented at the L3 level between two heterogeneous wireless networks under the proposed URRM internetworking architecture.

The SVM-based VHO decision system supports the adaptive feedback system to cope with the complex environment.

Extensive simulations are performed to evaluate performance of the proposed VHO algorithm. Performance of the proposed algorithm is evaluated in terms of data throughput and service cost with various scenarios including a variety of mixed traffic types and $\mathrm{MN}$ velocities.

The remainder of this paper is organized as follows. The fundamentals of SVM classification are discussed in section 2. In section 3, we propose the URRM architecture, L3 level VHO procedure and SVM-based VHO decision system. In section 4, we describe our simulation model and analyze performance of the proposed VHO algorithm compared to RSS based VHO algorithms. In section 5 , we conclude our paper, presenting further research issues.

\section{SVM Classification}

SVM has recently been introduced as a new technique for solving a variety of learning, classification and prediction problems. SVM originated as an implementation of Vapnik's structural risk minimization (SRM) principle, which minimizes the generalization error, i.e., true error on unseen examples ${ }^{[13]}$.

In this section, we briefly review some basic work on SVMs for classification problems that will be used in the proposed system. To explain the principles of SVMs, we first examine the simplest case, a two-class problem, where the classes are linearly separable. In this problem, the goal is to separate the two classes via a function that is induced from the available examples. Consider the example in Fig. 1. Many possible linear classifiers could separate the data, but only one can maximize the margin. This linear classifier is termed the optimal separating hyperplane.

Consider the problem of separating the set of training vectors belonging to two separate classes, 


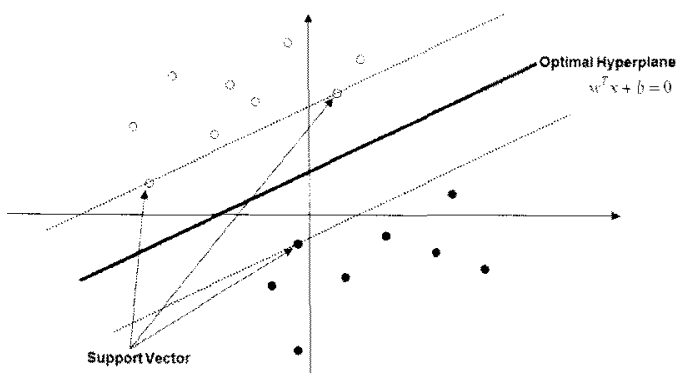

Fig. 1. Optimal separating hyperplane and support vectors

$$
D=\left\{\left(x^{1}, y^{1}\right), \cdots,\left(x^{l}, y\right)\right\}, x \in R^{n}, y \in\{-1,1\},
$$

With a hyperplane,

$$
w^{T} x+b=0
$$

If the set of vectors is separated without error and the distance between the closest vectors to the hyperplane is maximal, then this set is defined as optimally separated by the hyperplane. A separating hyperplane in canonical form must satisfy the following constraints,

$$
y^{i}\left[\left\langle w, x^{i}\right\rangle+b\right] \geq 1, i=1, \cdots, l .
$$

The distance $d(w, b ; x)$ of a point $\mathrm{x}$ from the hyperplane $(w, b)$ is,

$$
d(u, b ; x)=\frac{\left|\left\langle w, x^{i}\right\rangle+b\right|}{\|w\|} .
$$

Hence, the hyperplane that optimally separates the data is the one that minimizes the following:

$$
\begin{aligned}
& \min \Phi(w)=\frac{1}{2}\|w\|^{2} \\
& \text { s.t. } d_{i}\left(w^{x} x_{i}+b\right) \geq 1 \text { for } i=1, \cdots, l .
\end{aligned}
$$

The solution to the optimization problem of equation (5) is given by the saddle point of the Lagrange function:

$$
\Phi(w, b, \alpha)=\frac{1}{2}\|w\|^{2}-\sum_{i=1}^{l} \alpha_{i}\left(y^{i}\left[\left\langle w, x^{i}+b\right\rangle\right]-1\right),
$$

Where $\alpha$ are the Lagrange multipliers. The
Lagrangian has to be minimized with respect to $w$, $b$ and maximized with respect to $\alpha \geq 0$. Classical Lagrangian duality enables the primal problem, given by equation (6), to be transformed to its dual problem, which is easier to solve. The dual problem is given by:

$$
\begin{aligned}
& \max \Phi(\alpha)=\sum_{i=1}^{l} \alpha_{i}-\frac{1}{2} \sum_{i=1}^{l} \sum_{j=1}^{l} \alpha_{i} \alpha_{j} d_{i} d_{j}\left\langle x_{i} x_{j}\right\rangle \\
& \text { s.t. } \alpha_{i} \geq 0, i=1, \cdots, l \text { and } \sum_{i=1}^{l} \alpha_{i} d_{i}=0 .
\end{aligned}
$$

The hard classifier is then given by:

$$
f(x)=\operatorname{sgn}\left\{\sum_{i=1}^{Y} \alpha_{i} d_{i} K\left(x_{i}, x\right)+b\right\}
$$

\section{Proposed VHO Decision System}

In this section, we propose the URRM architecture, L3 level'VHO procedure and the SVM-based VHO decision system. URRM is devised to enable effective service provisioning in interworking architecture with 3GPP radio access and non-3GPP radio access.

\subsection{URRM Architecture}

We designed the URRM architecture by applying the CRRM server based centralized approach ${ }^{[14]}$ to the 3GPP interworking specification ${ }^{[15]}$, where the evolved packet core (EPC) provides interworking

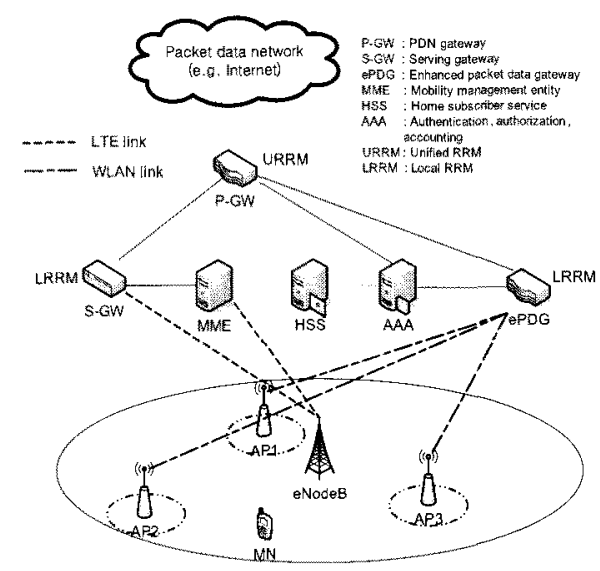

Fig. 2. URRM Interworking Architecture for LTE and WLAN access 
function between 3GPP and non-3GPP access networks.

We consider the LTE and the WLAN access systems, as 3GPP and non-3GPP accesses, respectively. As shown in Fig. 2, the LTE and the WLAN accesses are integrated through the PDN gateway (P-GW) in the EPC. The URRM entity is integrated into the P-GW, as a centralized resource managing entity. The LRRM entities of the LTE and the WLAN accesses are integrated into the serving gateway (S-GW) and the enhanced packet data gateway (ePDG), respectively.

\subsection{VHO Procedure}

Figure 3 shows the VHO procedure performed among URRM interworking elements in the case of VHO from WLAN to LTE. The reverse direction VHO procedure, i.e., VHO from LTE to WLAN, is not presented in this paper, because the overall procedure is similar to the procedure from WLAN to LTE.

Procedure 1 in Fig. 3 shows that each network element, a MN that has dual radio interfaces for WLAN and LTE system and local RRM entities, such as eNodeB and Access Point, needs to be registered to the URRM entity through its GLL. After registration, the LinkAttach message is sent from the URRM entity to the GLL of each element to set up a radio link. After reception of this message, the GLL initiates the setup of a $\mathbf{L} 2$ radio connection that leads to actual attachment. In this example procedure, a MN is assumed to be connected to the WLAN access networks. In such a scenario the MN is initially served by the WLAN network, but frequently requests Link quality information and listens to its interfaces to probe other connectivity opportunities in Fig. 4 Handoff Information Gathering. The $\mathrm{MN}$ reports the link measurements to the URRM entity either periodically or event triggered.

Procedure 2 shows a VHO initiation procedure. A MN periodically measures the signal strength sent from the eNodeB of the LTE system, as well as the current serving AP. When the measured received signal strength from the AP falls below a predefined trigger level, the MN initiates the handover procedure by sending the handover preparation message to the ePDG and the URRM entity. Upon receiving the handover request message from the MN, the URRM entity executes the SVM Pattern Classifier to find a possible access network (e.g., a LTE cell) that can support the connection to the MN in Fig. 4 Handoff Decision. Then the URRM entity responds to the $\mathrm{MN}$ about the new access network discovery result whether or not it is successful.

When it is successful, procedure 3 is executed in Fig. 4 Handoff Execution. In this procedure, the mobility management entity (MME) contacts the home subscriber service (HSS) entity and the authentication, authorization and accounting (AAA) entity to authenticate the $M N$ to the new access network (e.g., the LTE system). After successful

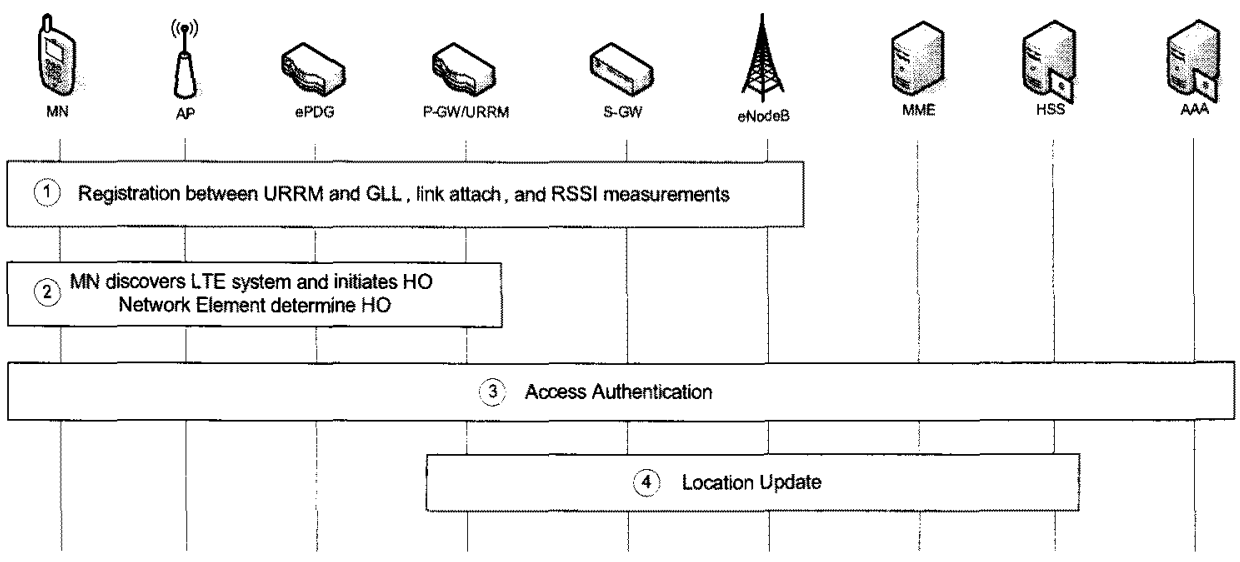

Fig. 3. A brief VHO Procedure from WLAN to LTE 


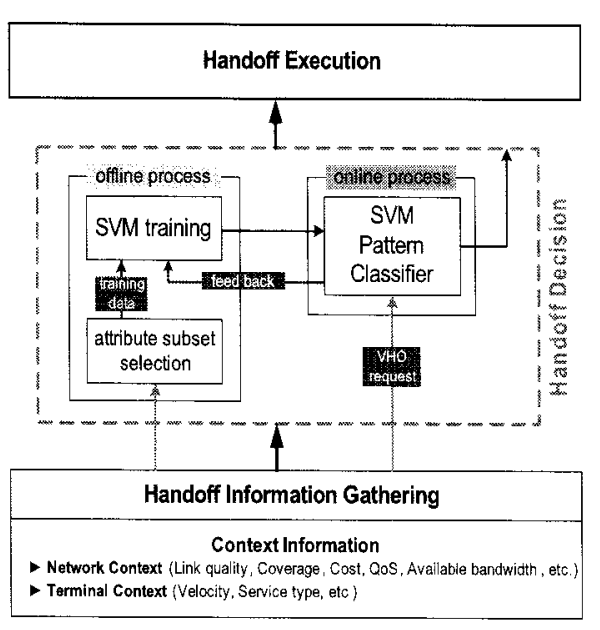

Fig. 4. Block diagram of the proposed SVM-based VHO decision system

authentication, the MME entity performs the location update procedure.

\subsection{SVM-based VHO decision system}

The proposed SVM-based VHO decision system is described in Fig. 4. As shown in Fig. 2, it is located in the URRM entity. The main phases of the handoff management process are shown in Fig. 4. : 1) Handoff Information Gathering; 2) Handoff Decision; and 3) Handoff Execution.

1) Handoff Information Gathering collects all the contextual information required to apply SVM training and to apply the VHO request, through monitoring and measurements. In our experiment, data training samples are obtained from our early work $^{[16]}$. Suggested context parameters that may be considered are:

- Terminal's context: velocity, service type

- Network context: link quality, coverage, cost, QoS, available bandwidth, etc.

2) Handoff Decision decides if a handoff is requested, it chooses the best target access network. The proposed VHO decision system is composed of three modules: The SVM Pattern Classifier module of one online process module, and the attribute subset selection and SVM training module of two offline process modules. a) The attribute subset selection module selects the optimal data attribute subset for SVM training that improves the accuracy and the classification speed of the entire SVM Pattern Classifier. After that, data sets are used in the SVM training module. b) The SVM training module performs training based on the attribute selection of the data for binary SVM classification, as mentioned in Section 2. SVM performs supervised learning on the training data set. c) The SVM Pattern Classifier module classifies the handoff request data by SVM training. They are applied on scenarios as follows: when a $\mathrm{MN}$ is moving out of the serving access network and will enter another access network shortly; or when a MN is connected to a particular network, but chooses to be handed over to another available access network for its future service needs. The proposed VHO decision system is a feedback system from the earlier result through principal component analysis to cope adaptively with the dynamic and complex future network environment.

3) Handoff Execution performs the Access Authenticate procedure. In this procedure, the mobility management entity (MME) contacts the home subscriber service (HSS) entity and the authentication, authorization and accounting (AAA) entity to authenticate the MN to the new access network as shown in Fig. 2. After successful authentication, the MME entity performs the location update procedure. Then, MN establishes the IP connectivity to ensure service continuity through the chosen access network.

\section{Performance Evaluation}

\subsection{Simulation Model}

Performance of the proposed VHO decision system is exploited under the URRM interworking architecture via extensive simulation analysis. As shown in Fig. 2, three WLAN hot spots are assumed to be located in a single LTE cell coverage. The cell radius of LTE and WLAN are assumed to be $1000 \mathrm{~m}$ and $250 \mathrm{~m}$, respectively. We assume the Gaussian Markov model ${ }^{[17]}$, where MNs moving toward the 
outside of the LTE cell are assumed to bounce back into the same cell for the mobility of $\mathrm{MNs}^{1181}$. We also assume that the WLANs are IEEE802.11n standard based systems capable of supporting up to $1 \mathrm{Gbps}$ of data rate and that the LTE standard based cellular system is able to support up to $100 \mathrm{Mbps}$ of data rate. Two service types, voice over IP (VoIP) and web traffic, are assumed to be used. Three different velocity models are assumed for MNs; a stationary model $(0 \mathrm{~km} / \mathrm{h})$, a pedestrian model (below $5 \mathrm{~km} / \mathrm{h}$ ), and a vehicular model (above 60 $\mathrm{km} / \mathrm{h}$ ). Performance of the proposed VHO algorithm is examined with a number of mixes of service types and velocity models.

Simulation parameters of the LTE system are summarized in Table 1. In order to reduce simulation time, we scale down the simulation parameters of both of LTE and WLAN systems, as shown in Table 2. Although this may leave the applicability of the analysis to a more realistic network environment in doubt, we believe the general trends obtained through scaled down simulation still remains valid.

Table 1. LTE frame simulation parameters

\begin{tabular}{|l|l|}
\hline \multicolumn{1}{|c|}{ Parameters } & \multicolumn{1}{|c|}{ Value } \\
\hline System & $\begin{array}{l}\text { SC-FDMA } \\
\text { (uplink) }\end{array}$ \\
\hline Bandwidth per Resource Block (RB) & $20 \mathrm{MHz}$ \\
\hline Frame duration & $10 \mathrm{~ms}$ \\
\hline Slot duration & $0.5 \mathrm{~ms}$ \\
\hline Number of subcarriers per RB & 12 \\
\hline Number of RB per slot & 100 \\
\hline Number of subcarriers per slot & 1200 \\
\hline
\end{tabular}

Table 2. Summary of simulation parameters

\begin{tabular}{|l|l|l|}
\hline \multicolumn{1}{|c|}{ Parameters } & \multicolumn{1}{|c|}{ LTE } & \multicolumn{1}{c|}{ WLAN } \\
\hline Capacity & $100 \mathrm{Mbps}$ & $1 \mathrm{Gbps}$ \\
\hline $\begin{array}{l}\text { Number of block } \\
/ \text { frame per 10 ms }\end{array}$ & 2000 & 500 \\
\hline Simulation Capacity & $1 \mathrm{Mbps}$ & $10 \mathrm{Mbps}$ \\
\hline $\begin{array}{l}\text { Simulation number of RB } \\
/ \text { frame per 10 ms }\end{array}$ & 20 & 5 \\
\hline Block / Frame size & 62.5 bytes & 2500 bytes \\
\hline
\end{tabular}

\subsection{Performance Metrics}

We evaluate performance of the proposed VHO decision system in terms of throughput and usage cost with respect to different numbers of concurrent users (i.e., the traffic load) via extensive simulations. We compare the performance of the proposed adaptive VHO algorithm to that of the RSS based VHO algorithm ${ }^{[19]}$.

\subsection{Performance Evaluation}

Figure 5 compares throughput performance of the WLAN system for the proposed VHO algorithm to that of the RSS based VHO algorithm with respect to the traffic load. The percentages of voice and web users are set equal. Two types $(5 \mathrm{~km} / \mathrm{h}$ and $60 \mathrm{~km} / \mathrm{h})$ of velocity models are used, with three different mixtures: $20 \%$ vs. $80 \%, 50 \%$ vs. $50 \%$, and $80 \%$ vs. $20 \%$. The simulation shows that as the traffic load increases, throughput performance of the WLAN system is enhanced. The proposed VHO algorithm outperforms the RSS based VHO algorithm for all cases of the velocity mixtures. Since the signal strength from APs is less than that from LTE, VHO from LTE to WLAN is not executed with the RSS based VHO algorithm in some WLAN coverage area, especially in the AP1 hot spot area in Fig. 2. In contrast, instead of using the measured RSS value, the proposed VHO algorithm uses the seven level abstraction value of MIVI that is equally applied to each system. In addition, the proposed VHO algorithm considers other decision factors, such as the available bandwidth and usage cost. As a result, the proposed

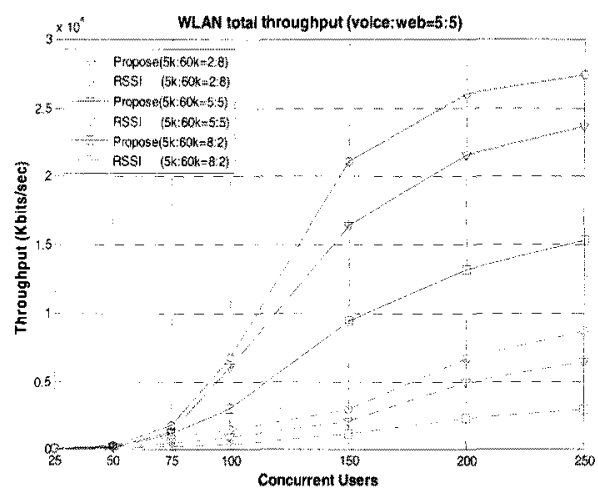

Fig. 5. WLAN total throughput 
VHO algorithm outperforms the RSS based VHO algorithm.

Figure 6 compares throughput performance of the LTE system for the proposed VHO algorithm to that of the RSS based VHO algorithm under the same circumstances. The simulation shows that as the traffic load increases, throughput performance of the LTE system with the proposed algorithm is enhanced to a certain point (up to 75 concurrent users) and slowly decreases, since the LTE system is fully loaded when the number of concurrent users reaches 75; after that, more web traffic users tend to be handed over to the WLAN systems. Consequently, after 75 users throughput of the LTE system begins decreasing. In contrast, throughput performance of the LTE system with the RSS based VHO algorithm is higher than that with the proposed VHO algorithm with fewer than 75 concurrent users; due to the same reason explained in the previous paragraph (i.e., the wider coverage

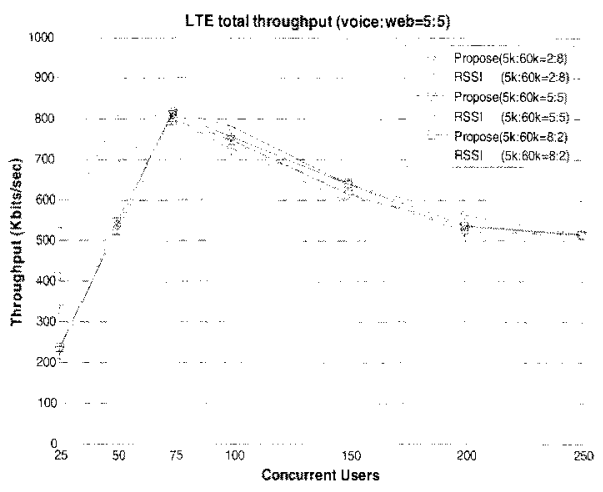

Fig. 6. LTE total throughput

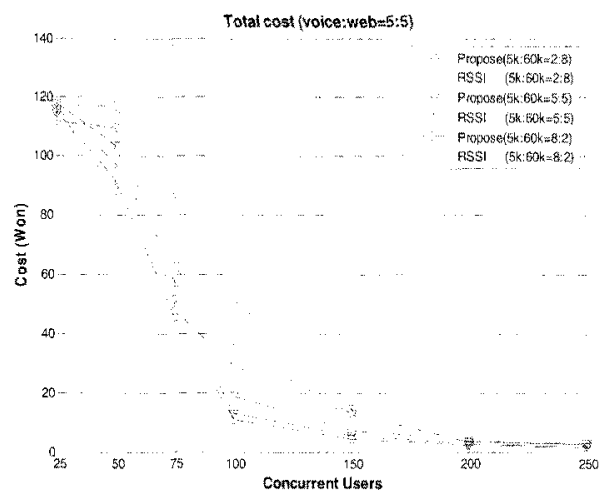

Fig. 7. Total cost area of LTE system), the LTE system accommodates more web traffic users in this phase. Therefore, the LTE system reaches its capacity limit with the RSS based VHO algorithm faster than with the proposed VHO algorithm.

Figure 7 shows the average usage cost per user. In this case, the proposed VHO algorithm outperforms the RSS based algorithm, since the proposed algorithm takes the usage cost into account for VHO decision making, while the RSS based VHO algorithm does not.

\section{Conclusion}

In this paper, we proposed the URRM architecture and a SVM-based VHO decision system which is a pattern recognition approach between the 3GPP LTE and the next generation WLAN systems. Simulations show that the proposed VHO algorithm outperforms RSS based VHO algorithms in terms of throughput and service cost.

Although the proposed decision scheme based on the SVM requires relatively long training time, it is fast in making the VHO decision. The fast VHO decision seems to be particularly advantageous in the beyond $4 \mathrm{G}$ (B4G) environment where cells with small coverage such as femtocells and WLANs are likely coexist with macro cells.

However, there remain further study issues. First, the approach described for a linear SVM can be extended to create a nonlinear SVM (SVDD) for classifying linearly inseparable data. Second, the handoff algorithm based on pattern recognition can be extended to other possible performance criteria. Various feature extractors, pattern classifiers, and neural network architectures will be incorporated. Finally, unsupervised learning methods can be applied to eliminate the necessity of training runs.

\section{References}

(1) Gustafsson. E and Jonsson. A, "Always best connected," IEEE Wireless Comm., Vol.10, No. 1, pp.49-55, Feb. 2003.

[2] Rubaiyat Kibria. M and Abbas Jamalipour, "On 
designing issues of the next generation mobile network," IEEE Network, Vol.21, pp.6-13, Feb 2007.

[3] Balasubramaniam. S and Indulska. J, "Vertical Handover Supporting Pervasive Computing in Future Wireless Networks," Computer Comm., Vol.27, pp.708-719, 2004.

(4) Huang. L et. Al, "Network-centric user assignment in the next generation mobile networks," IEEE Comm. Letters, Vol.10, No. 12, pp.822-824, Dec. 2006.

(5) Sur. A and Sicker. D.C., "Multi layer rules based framework for vertical handoff," BroadNets 2005, Vol.1, pp.571-580, Oct. 2005.

[6] Perez-Romero. J et. Al., "Policy-based initial rat selection algorithms in heterogeneous networks," MWCN 2005, Sep. 2005.

(7) Zhang. W, "Handover decision using fuzzy MADM in heterogeneous networks," IEEE WCNC, Vol.2, pp.653-658, Mar. 2004.

[8] Maturino-Lozoya. H. "Pattern Recognition Techniques in Handoff and Service Area Determination," VTC, Vol.1, pp.96-100, Jun. 1994

[9] Kennemann. O, "Pattern recognition by hidden markov models for supporting handover decisions in the GSM system," Digital Mobile Radio Comm., pp.195-202, June 1994.

[10] Narasimhan. R and Cox. D.C., "A handoff algorithm for wireless systems using pattern recognition," Personal, Indoor, Mobile Radio Comm., Vol.1, pp 335-339, Sep. 1998.

[11] Doulamis. A.D et. Al., "An adaptable neural-network model for recursive nonlinear traffic prediction and modeling of MPEG video sources," Neural Networks, Vol.14, No.1, pp.150-166, Jan. 2003.

(12) Jaehak Yu et. Al., "Real-time Classification of Internet Application Traffic using a Hierarchical Multi-class SVM," TIIS Vol.4, No.5, Oct. 2010, pp.859-876.

[13] Vapnik V.N. The nature of statistical learning theory. Springer-Verlag New York, 1995.

[14] Leijia Wu and Sandrasegaran. K, "A Survey on Common Radio Resource Management,"
AusWireless 2007, pp.66-71, Aug. 2007.

[15] 3GPP TS 23.402, "Technical Specification Group Services and System Aspects; Architecture enhancements for non-3GPP accesses (Rel. 9)", July 2009.

[16] Tae-sub Kim et. Al., "Vertical Handover between LTE and Wireless LAN Systems based on Common Resource Management and Generic Link Layer," ICCIT 2009, pp.66-71, Nov. 2009.

(17) Abbas Jamalipour, The wireless mobile Internet-architectures, protocols and services, Wiley, 2003.

[18] IST EVEREST Project, "Target Scenarios Specification," EVEREST IST-2002-001858 D 5, Apr. 2004.

(19) Pollini, G.P., "Trends in Handover Design," Comm. Magazine, Vol.34, pp.82-90, Mar 1996.

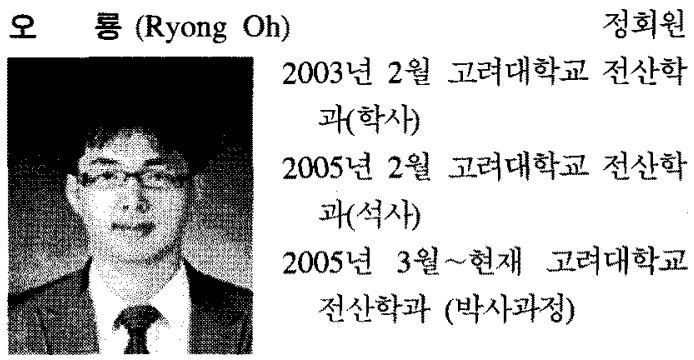

<관심분야> 이동통신시스템 설계 및 성능 분석, MAC 프로토콜



정회원 2001년 건국대학교 전산과학과 (학사) 2003년 고려대학교 전산학과 (석사)

2010년 고려대학교 전산학과 (박사)

2010년 현재 한국전자통신연 구원

<관심분이> 데이터 마이님, RFID/USN, 기계학습, 멀티미디어 마이닝, 네트워크 마이닝 


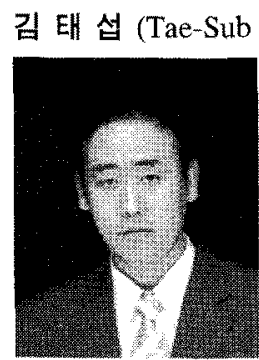

Kim)

정회원

2006년 고려데학교 컴푸터정보 학과(학사)

2008년 고려대학교 컴퓨터정보 하괏석사)

2008년 현재 고려대학고 컴푺

터정보학자 (박사과정)

<관심분야> 이동통신, 무선자

읜관리, 멤토셀, 무전보안, IT 응합



종신회원

1988년 고려대학교 산업 공학 과 학사

1991년 고려대학교 산업 공학 과 석사

2003년 뉴욕주립데 (SUNY at

Buffalo) 산업공학과 박사

1991 1993년 LG전자 형상미

디어연구소 (주임연구원)

1993 2004년 한국전자통신연구원 이동통신연구단

(선임연구원)

2004년 현재 중앙데학교 정보시스템학과 교수

<관심분야> 이동통신시스템 설계 및 성능 분석, 무

선 $\mathrm{MAC}$ 프로토콜, 컴퓨터 녜트워크

조 충 호 (Choong-Ho Cho)

종신회원



정히원

2004년 2월 고려대학교 전산학 과(학사)

2006년 2월 교러대학교 전산학 피(석사)

2006년 3월 현재 고려대학교 전산학과 (박사과정)

<관심분야> 이동성 관리, 통시

망 설계 및 성능 분석



1981년 2월 고려대학교 산업공 학과

1993년 2월 고려데학교 산업공 학과 석사

1986년 프랑스 INSA de Lyon 전산학과(석사)

1989년 프랑스 INSA de Lyon 전산학과(박사)

1990년 1994년 순천향대학고 전산통계학과 조그누 1994년 현재 고려대학교 전산학과 교수

<관심분야> 통신망 트래픽 관리기술, 무선통신 시 스템, 멀티미디어통신, 인터넻 비즈니스 